\title{
Physical factors contributing to the benthic dominance of the alga Caulerpa sertularioides (Caulerpaceae, Chlorophyta) in the upwelling Bahía Culebra, north Pacific of Costa Rica
}

\author{
Cindy Fernández-García ${ }^{1,2,3}$, Jorge Cortés ${ }^{1,2}$, Juan José Alvarado ${ }^{1,3}$ \& Jaime Nivia-Ruiz ${ }^{1}$ \\ 1. Centro de Investigación en Ciencias del Mar y Limnología (CIMAR), Ciudad de la Investigación, Universidad de \\ Costa Rica, San Pedro, 11501-2060 San José, Costa Rica; cindy@biologia.ucr.ac.cr \\ 2. Escuela de Biología, Universidad de Costa Rica, San Pedro, 11501-2060 San José, Costa Rica. \\ 3. Posgrado en Ciencias Marinas y Costeras, Universidad Autónoma de Baja California Sur, Carretera al sur km 5.5, La \\ Paz, C.P. 23080, México.
}

Received 28-II-2011. Corrected 28-VI-2011. Accepted 05-III-2011.

\begin{abstract}
Caulerpa sertularioides has been spreading in Bahía Culebra, a seasonal upwelling bay in the north Pacific of Costa Rica, since 2001. The survey was carried out from December 2003 to March 2005, in several locations around Bahía Culebra, located inside the Gulf of Papagayo. This study investigated spatial and temporal patterns, percent coverage, monthly growth rate, reproductive adaptations, and morphological variations of frond length and stolon diameter of Caulerpa sertularioides, at different environmental physical and chemical factors at the bay. The alga extended to depths of $23 \mathrm{~m}$ on a variety of substrates. The stolons extended quickly, with a maximum growth rate of $31.2 \mathrm{~cm} \mathrm{month}^{-1}$. This alga grows mainly by fragmentation of its fronds and stolons; nevertheless it can also reproduce sexually by releasing gametes in the water column. These two modes of spreading promote the adaptation of this opportunistic species to environmental, chemical, and physical changes at this bay. At the same time the alga showed variations in the length of its fronds and stolons, adapting to conditions such as depth and season. Average percent cover and frond density increased during the dry season when the upwelling of nutrients and cold water occurs. In the rainy season the average percent cover and frond density decreased; however there was a peak in September, when high precipitation resulted in runoff into the bay of nutrient-rich waters. The morphological and physiological plasticity of $C$. sertularioides, in synergy with its predominant clonal propagation and sexual reproduction provided this species with a great adaptability to changes in temperature and nutrient concentration at Bahía Culebra. Rev. Biol. Trop. 60 (Suppl. 2): 93-107. Epub 2012 April 01.
\end{abstract}

Key words: Caulerpa sertularioides, Bryopsidales, Central America, growth rates, nutrients, seasonal upwelling.

The genus Caulerpa has 86 current accepted species (Guiry \& Guiry 2011) distributed throughout the world oceans, and in Central America 8 species have been reported (Fernández-García et al. 2011). It is a common inhabitant of intertidal and subtidal tropical and semitropical marine waters. These algae have a creeping green stolon with root-like colorless rhizoids and erect uprights called fronds (Lee 2008). Propagation of Caulerpa is mainly clonal, and its phenotypic plasticity provides an opportunity to adapt to different changes in physical environments (Sernerpont et al. 2003). Most species in the genus have been studied, mainly due to its invasive capacity and the consequent economical impact on coastal communities (Knowlton 2000, West et al. 2009).

The species Caulerpa sertularioides (S.G. Gmelin) Howe, 1905, is characterized by feather-like fronds, sometimes branched, with cylindrical and needle shaped branchlets 20 cm length and 1-2 cm wide (Howe 1905). This 
species is distributed within tropical and subtropical waters and is most commonly observed forming patches in benthic sandy habitats and growing within the seagrasses to a depth of 10 m (Schnetter \& Bula-Meyer 1982, Littler \&Littler 2000). Despite its broad distribution, studies on this species are scarce in comparison with other Caulerpa species (Scrosati 2001).

In the Eastern Tropical Pacific (ETP), Caulerpa sertularioides is distributed from the Gulf of California, Mexico (Dawson 1944) to a reported southern limit of Gorgona Island, Colombia (Schnetter \& Bula-Meyer 1982). It has been reported for Mexico (Taylor 1945, Scrosati 2001), Nicaragua (Dawson 1962), Costa Rica (Fernández \& Cortés 2005), Panama (Wysor 2004, Smith et al. 2010) and Colombia (Schnetter \& Bula-Meyer 1982).

In the Pacific coast of Costa Rica, at Bahía Culebra, a coastal upwelling zone, this green alga has been spreading around the bay since 2001 (Fernández \& Cortés 2005). As a result, C. sertularioides has become dominant with the subsequent replacement of native algae species and overgrowth on coral colonies. This has caused changes on the local diversity and abundance of benthic flora and fauna (Fernández \& Cortés 2005). In other regions of the Eastern Pacific, C. sertularioides has exhibited similar bloom patterns, some of them ephemeral such in Panama (Glynn \& Maté 1997) and Gulf of California (Scrosati 2001), while in Costa Rica and other localities of Panama (Fernández \& Cortés 2005, Smith et al. 2010) the alga has maintained high densities over several years.

Under specific conditions Caulerpa species can easily spread and cover high percentages of the substrate (Withgott 2002). Is well-known, that the spreading of some species of Caulerpa is triggered by changes in environmental conditions such as: water temperature, an increase in nutrient concentrations and light intensity (Raven \& Geider 1988, Bell 1992, Lapointe 1997, Scrosati 2001, Malta et al. 2005). Furthermore, this factors, combined with water motion and depth, can induce variations in the morphology, which is an advantage in adapting to different environments (Ohba et al. 1992,
Collado-Vides \& Robledo 1999, De Senerpont Domis et al. 2003, Malta et al. 2005).

In addition the spreading of Caulerpa species is favored by intrinsic characteristics of this genus, such as toxins to avoid herbivory, morphological and physiological plasticity, asexual reproduction by fragmentation (Graham et al. 2009), rapid nutrient uptake, rapid lateral growth of stolons and fragments, and associations with unpalatable species (Tyler et al. 2010).

In the Gulf of California, Scrosati (2001) found that water temperature is one of the most important abiotic factors that affect growth rates of $C$. sertularioides. However there are few studies to date on other factors favoring the spreading of this species and how these factors influence the morphology of this species. This is why the objectives of the present study were to describe the spreading of this alga in an upwelling region and to determine those factors that influence the spreading of $C$. sertularioides, by analyzing the spatial and temporal coverage, density and growth rates patterns. Also to determine, if there are morphological adaptations, of fronds and stolons, in relation to environmental conditions.

\section{MATERIALS AND METHODS}

Study site: The survey was carried out in Bahía Culebra $\left(10^{\circ} 35^{\prime} \mathrm{N}-85^{\circ} 40^{\prime} \mathrm{W}\right)$, located in the Gulf of Papagayo, north Pacific coast of Costa Rica, from December 2003 to March 2005. This bay extends from Islas Huevos to Islas Pelonas, including the inner part of the bay, Puerto Culebra and the Iguanita mangrove (Jiménez 2001) (Fig. 1). The Gulf of Papagayo is highly influenced by trade winds that move southward during the dry season (December to April). These winds displace surface waters away from the coast. This results in the upwelling of cold and nutrient rich water (Brenes et al. 1995, Jiménez \& Cortés 2003). During the dry season, when upwelling occurs, the mean water temperature is $22.9 \pm 0.3^{\circ} \mathrm{C}$, while during the wet, non-upwelling season (May-November) 


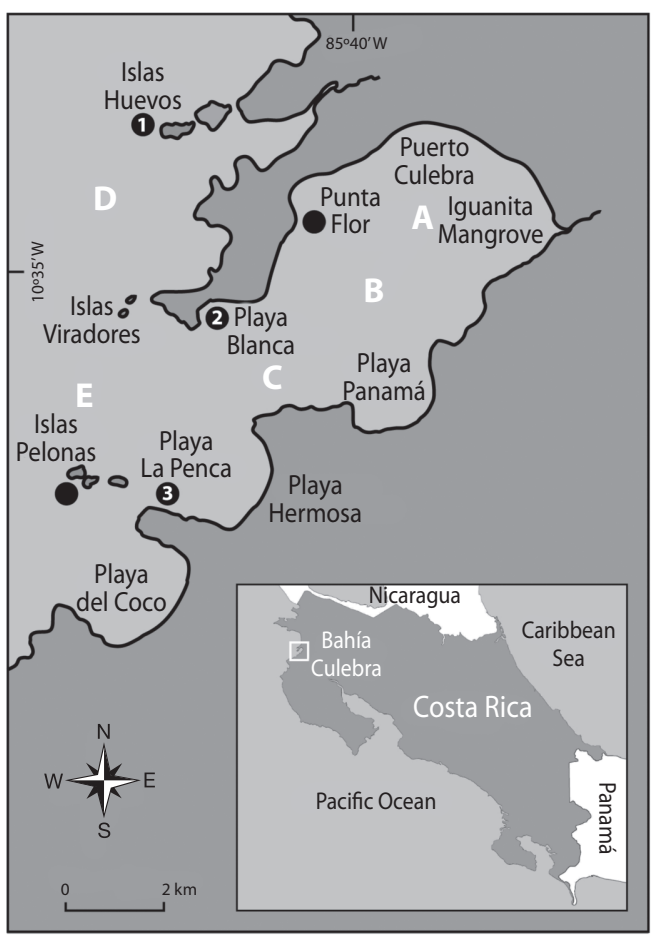

Fig. 1. Black dots indicate the location of the sites where environmental factors were measured. Numbers indicate sites were we quantified percent coverage and frond density of Caulerpa sertularioides within fixed quadrats from March 2004-March 2005. Letters indicate sites where we monitored nutrient concentrations.

Fig. 1. Los círculos negros indican la posición donde se tomaron los factores ambientales. Los números indican los sitios donde se midió el porcentaje de cobertura y la densidad de frondas de Caulerpa sertularioides en cuadrículas permanentes, desde Marzo 2004-Marzo 2005. Las letras indican los sitios donde se monitoreo la concentración de nutrientes.

the temperature rises to a mean of $27.0 \pm 0.1^{\circ} \mathrm{C}$ (Jiménez \& Cortés 2003).

Environmental conditions: The following environmental factors were measured monthly at five sites: Islas Huevos, Playa Blanca, Punta Flor, La Penca and Isla Pelonas (Fig. 1): Salinity $(\%$ ) , using a manual refractometer (ATAGO, model S/Mill-E). Temperature $\left({ }^{\circ} \mathrm{C}\right)$, measured at 30 min intervals with in situ continuous logging sensors (Stow Away XTI) located at each site, converted to monthly mean averages for the analysis. As an indirect measurement of primary productivity, we measured the concentration of chlorophyll $a\left(\mu \mathrm{g}^{-1}\right)$ according to Lorenzen and Jeffrey (1978). Also we calculated the concentration of suspended sediments $\left(\mathrm{mg} \mathrm{l}^{-1}\right)$, collected with a 3.81 bottle, filtered with fiberglass filters (Whatman GF/C) that were dried and weighted, and sedimentation rate $\left(\mathrm{mg} \mathrm{cm}^{-2}\right.$ day $\left.^{-1}\right)$ measured with three sediment traps at each sampling site, following the methodology of Cintrón et al. (1994) and Rogers et al. (1994). These two last factors were measured as an indirect measurement of runoff.

Nutrients were analyzed from water samples collected with a Niskin bottle at $15 \mathrm{~m}$ deep, at five sites in the bay (Fig. 1). Each sample was transferred to $1 \mathrm{~L}$ dark bottles, which were placed in a cooler with ice. We estimated the concentration $(\mu \mathrm{M})$ of: phosphate $\left(\mathrm{PO}_{4}^{-3}\right)$, nitrite $\left(\mathrm{NO}_{2}^{-}\right)$, nitrate $\left(\mathrm{NO}_{3}{ }^{-}\right)$, ammonium $\left(\mathrm{NH}_{4}^{+}\right)$and silicate $\left(\mathrm{SiO}_{4}\right)$. These nutrients were measured following Strickland \& Parsons (1972) and the protocol of the Chemical Oceanography Laboratory of the Centro de Investigación en Ciencias del Mar y Limnología (CIMAR).

To determine climatic changes, precipitation $(\mathrm{mm})$, solar intensity (sun hours day ${ }^{-1}$ ) and wind velocity $\left(\mathrm{km} \mathrm{h}^{-1}\right)$ data were obtained from the National Meteorological Institute of Costa Rica, at the Daniel Oduber Quirós International Airport Station (10 $35^{\circ}$ N-85 $32^{\circ}$ $\mathrm{W}, 80 \mathrm{~m}$ above sea level); the closest station to Bahía Culebra.

To determine the most important marine environmental factors influencing Bahía Culebra, we applied a principal component analysis (PCA) based on a correlation matrix (Clarke \& Warwick 1994) using the mean value per month of each environmental variable. Once we determined the most important environmental factors, graphed the average per month and we applied a Kruskal-Wallis non parametric analysis to determinate whether or not these factors vary between the dry and wet season. All the statistical analyses were performed using the software Systat 8.0 and JMP IN 4.0.4. 
Ecology and morphology of Caulerpa sertularioides: With a manta tow method (Rogers et al. 1994), we identified the main C. sertularioides patches in Bahía Culebra. At each site we recorded the maximum and minimum depth where the alga was growing.

In order to determine morphological variations of the fronds and stolons of C. sertularioides at different depths and seasons, we collected thalli of the green alga, in March 2004 (dry season) and in October 2004 (rainy season), at three depths and from three different sites as replicates: $2 \mathrm{~m}$ (Playa La Penca, Islas Huevos and Punta Flor), $5 \mathrm{~m}$ (Playa La Penca and Playa Blanca) and $10 \mathrm{~m}$ (Playa La Penca, Islas Huevos and Islas Pelonas). According to Meinesz et al. 1995, Dumay et al. 2002 and De Senerpont Domis et al. (2003), who found that fronds and stolons vary with physical conditions, we chose frond length and stolon diameter as morphological measurements. Therefore, we randomly chose 50 fronds and 50 stolons from each sample. We photographed each section of the thallus and digitized frond length and stolon diameter (UTHSCSA software Image Tool version 3.0). For each parameter, we took 3-5 measurements and we calculated an average per thallus. To determine if morphological characteristics varied between depths, we applied an analysis of variance (ANOVA) and an a posteriori test (Tukey), for each factor. Frond length data were $\log _{10}(x+1)$ transformed, while stolon diameter data fit a normal distribution.

Growth rate: Growth rate of $C$. sertularioides was estimated from stolon growth rates per month. In situ measurements of re-growth stolon length at three sites in the bay (Islas Huevos, Playa Blanca and Playa La Penca: Fig. 1) were collected at approximately $4 \mathrm{~m}$ deep. At each site, we removed all the thali from five permanent $50 \mathrm{~cm}^{2}$ quadrats, marked with construction rods, located over a patch of $C$. sertularioides. After a month, we measured all the re-growth stolons inside the fixed quadrat using a caliper $( \pm 0.05 \mathrm{~mm})$. Plots were cleared at the end of November 2003, February 2004 and August 2004 and were allowed to re-grow until the end of December 2003, March 2004, and September 2004. Finally, we applied an ANOVA and a posteriori Tukey test to determine differences between growth rates, at each month. The stolon length data were $\log _{10}$ $(\mathrm{x}+1)$ transformed.

Temporal algal percent coverage and frond density: Between March 2004 and March 2005 we measured the frond density and percent coverage of $C$. sertularioides monthly, at three sites in the bay: Islas Huevos, Playa Blanca and Playa La Penca (Fig. 1). At each site we calculated the percent coverage, as a visual estimation of how much substrate fronds and stolons cover the substrate, from five 50 x $50 \mathrm{~cm}^{2}$ quadrats permanently located over a $C$. sertularioides patch. From these quadrats we choose six $10 \mathrm{~cm}^{2}$ subquadrats where we counted the fronds. Finally, to determine coverage and frond density differences between sites and seasons we applied an ANOVA. Data were tested for assumptions of normality and homogeneity and were transformed with Box-Cox.

\section{RESULTS}

Environmental factors: Bahía Culebra has high local seasonality, primarily related to precipitation, number of solar hours, and wind velocity (Table 1 ). The rainy season begins in May and ends in October, the rainiest months of this season are September and October. The dry season extends from December to April. Relative to the rainy season, the dry season had $212 \mathrm{~mm}$ less precipitation, an average of three more hours of sun light and an increase of 8.8 $\mathrm{km} \mathrm{h}^{-1}$ in wind velocity (Table 1 ).

According to the Principal Component Analysis (PCA), five main environmental factors explained $65.2 \%$ of the variance of the environmental conditions in Bahía Culebra from March 2004 to March 2005. Nitrate, phosphate and suspended sediments (PC1) contributed $26.7 \%$ of the variance, while sedimentation rate contributed $22.5 \%$ (PC2) and temperature contributed $16.0 \%$ (PC3) (Fig. 2). 
TABLE 1

Monthly mean, maximum and minimu values of physical-chemical parameters of Bahía Culebra monitored from March 2004 to March 2005

CUADRO 1

Promedio mensual, máximos y mínimos valores de los parámetros físico-químicos monitoreados en Bahía Culebra desde Marzo 2004 a Marzo 2005

\begin{tabular}{lccccc}
\multicolumn{1}{c}{ Variable } & Mean $\pm \mathrm{SD}$ & Maximum & Minimum & $\begin{array}{c}\text { Mean } \pm \text { SD Dry season } \\
(\text { Nov-Apr) }\end{array}$ & $\begin{array}{c}\text { Mean } \pm \text { SD Wet season } \\
\text { (May-Oct) }\end{array}$ \\
Precipitation $(\mathrm{mm})$ & $118.5 \pm 131.4$ & 410.9 & 0 & $4.1 \pm 6.5$ & $216.4 \pm 101.0$ \\
Solar radiation $\left(\mathrm{h} \mathrm{day}^{-1}\right)$ & $7.8 \pm 1.7$ & 10.3 & 5.5 & $9.4 \pm 0.7$ & $6.4 \pm 0.7$ \\
Wind velocity $\left(\mathrm{km} \mathrm{h}^{-1}\right)$ & $13.2 \pm 6.0$ & 27.0 & 6.7 & $17.9 \pm 5.5$ & $9.1 \pm 2.0$ \\
Temperature $\left({ }^{\circ} \mathrm{C}\right)$ & $27.2 \pm 1.81$ & 29.6 & 22.9 & $26.1 \pm 1.6$ & $28.5 \pm 0.5$ \\
Salinity $(\% o)$ & $32.8 \pm 1.61$ & 34.3 & 30.0 & $32.6 \pm 1.8$ & $33.0 \pm 1.2$ \\
Chlorophyll $a\left(\mu \mathrm{g} \mathrm{l}^{-1}\right)$ & $1.3 \pm 0.87$ & 3.8 & 0.4 & $1.1 \pm 0.3$ & $1.6 \pm 1.1$ \\
Suspended sediments $\left(\mathrm{mg} \mathrm{l}^{-1}\right)$ & $6.2 \pm 2.08$ & 10.2 & 3.3 & $5.8 \pm 2.2$ & $6.6 \pm 1.7$ \\
Sedimentation rate & $3.0 \pm 0.78$ & 4.8 & 2.1 & $3.0 \pm 0.9$ & $3.1 \pm 0.5$ \\
$\left(\mathrm{mg} \mathrm{cm}^{-2}\right.$ day $\left.{ }^{-1}\right)$ & $0.48 \pm 0.35$ & 1.45 & 0.03 & $0.49 \pm 0.4$ & $0.47 \pm 0.2$ \\
$\mathrm{PO}_{4}^{-3}(\mu \mathrm{M})$ & $0.27 \pm 0.39$ & 1.18 & od & $0.10 \pm 0.1$ & $0.46 \pm 0.5$ \\
$\mathrm{NO}_{2}^{-}(\mu \mathrm{M})$ & $2.34 \pm 4.35$ & 15.60 & od & $2.38 \pm 5.4$ & $2.30 \pm 1.9$ \\
$\mathrm{NO}_{3}^{-}(\mu \mathrm{M})$ & $0.06 \pm 0.16$ & 0.52 & od & $0.11 \pm 0.2$ & od \\
$\mathrm{NH}_{4}^{+}(\mu \mathrm{M})$ & $1.11 \pm 1.71$ & 5.88 & od & $1.10 \pm 1.0$ & $1.12 \pm 2.1$ \\
$\mathrm{SiO}_{4}(\mu \mathrm{M})$ & & &
\end{tabular}

1. $\mathrm{od}=$ off detection limit.

Of these factors, only the mean temperature was significantly different between seasons $\left(\mathrm{F}_{1,11}=12.099, \mathrm{P}<0.005\right)$.

Water temperature exhibited high seasonality, showing decreased temperatures in the dry season, when the wind velocity increased, producing a displacement of the thermocline to the surface and coastal upwelling (Table 1, Fig. 3A). The lowest temperature was recorded in March $2004\left(22.9^{\circ} \mathrm{C}\right.$, dry season), while the highest was recorded in September 2004 $\left(29.6^{\circ} \mathrm{C}\right.$, wet season). Salinity was higher during the dry season $(34.3 \%$ ) and lowest $(30.0 \%$ ) during the rainy season (Table 1 ). The highest chlorophyll $a$ concentration $\left(3.8 \mu \mathrm{g} \mathrm{l}^{-1}\right)$ was recorded in October (wet season) (Table 1). Suspended sediments showed similar fluctuation patterns to precipitation during the wet season, when streams and rains carry sediments and nutrients into the sea (Table 1, Fig. 3A). Sedimentation rates were less variable than suspended sediments (Table 1, Fig. 3A).
Nutrient concentration differed between seasons. Average phosphate, nitrate and ammonium were higher in the dry season, while average silicate and nitrite were higher during the wet season (Table 1). However, nutrient concentrations were highly variable within seasons. phosphate increased in December 2004 $\left(\mathrm{PO}_{4}{ }^{-3}=1.45\right)$ and September $\left(\mathrm{PO}_{4}^{-3}=0.69 \mu \mathrm{M}\right)$, while nitrate was higher in December 2004 $\left(\mathrm{NO}_{3}{ }^{-1}=15.6 \mu \mathrm{M}\right)$ (Fig. 3B)

Ecology and morphology of Caulerpa sertularioides: We found C. sertularioides ranged in Bahía Culebra from the intertidal zone to $23 \mathrm{~m}$ deep. It was present on different substrates (rocks, sand, and live and dead corals) forming patches that can cover 6 ha. The greatest coverage $(\sim 90 \%)$ was observed in sites between 3 to $6 \mathrm{~m}$ deep, where we found 108 fronds $10 \mathrm{~cm}^{-2}$. However, at depths $>12 \mathrm{~m}$, the coverage and frond density decreased, and only isolated stolons were observed. 
A

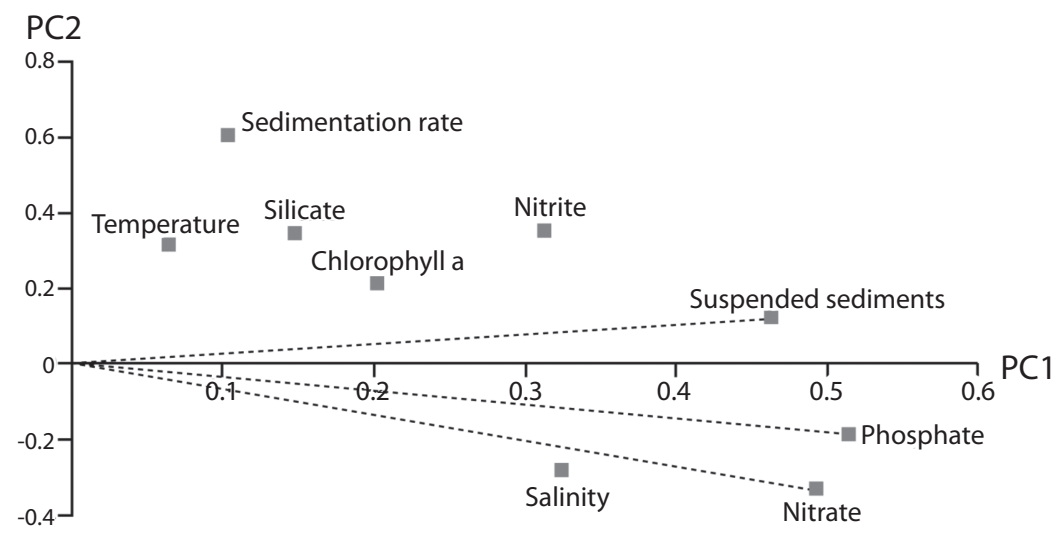

B

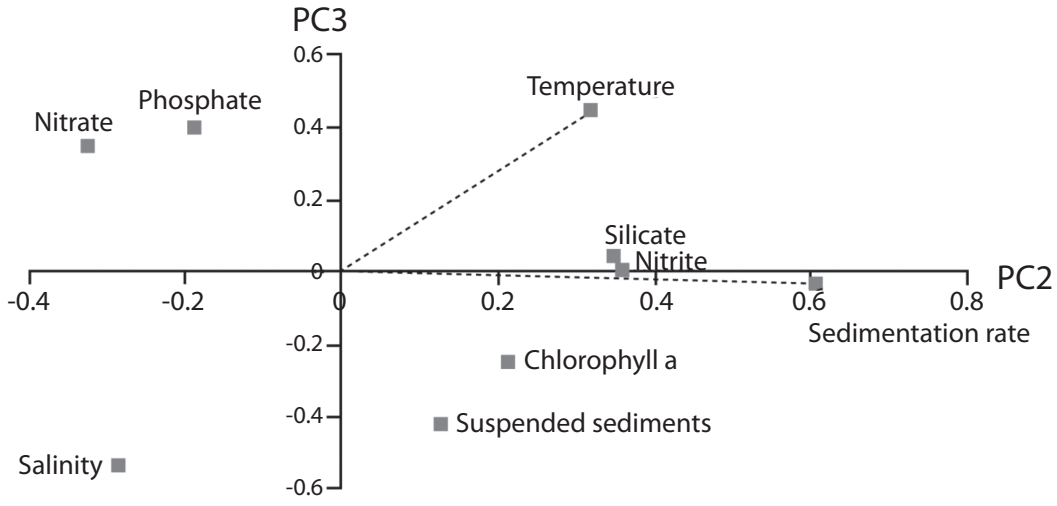

Fig. 2. Principal component analysis (PCA) of physical-chemical factors monitored at Bahía Culebra from March 2004March 2005. (A) Principal component 1 (PC1) vs Principal component 2 (PC2); (B) Principal component 2 (PC2) vs Principal component 3 (PC3). The three components explain $65.2 \%$ of the total variation.

Fig. 2. Análisis de Componentes Principales (PCA) de los factores físico-químicas monitoreadas en Bahía Culebra desde Marzo 2004-Marzo 2005. (A) Componente principal 1 (PC1) vs Componente principal 2 (PC2); (B) Componente principal 2 (PC2) vs Componente principal 3 (PC3). Los tres componentes explican un $65.2 \%$ de la variación total.

We also observed some algal patches simultaneously releasing gametes (Fig. 4A) at Punta Flor at 07:40 a.m., on January $3^{\text {rd }} 2005$ (Fig. 1). After gamete releases finished, all stolons and fronds turned white (Fig. 4B). This signal was later used to recognize other spawning events. Thus, most spawning events were observed in months when water temperature changes occured (February 2004, January 2005) and rain intensity was high (October 2004).
Caulerpa sertularioides showed different frond lengths at different depths (Fig. 5). The average stolon diameter of all the thalli measured was $0.18 \mathrm{~mm}(\mathrm{Min}=0.04 \mathrm{~mm}, \operatorname{Max}=0.34$ $\mathrm{mm}$ ), while frond length average was $5.3 \mathrm{~cm}$ $(\mathrm{Min}=0.79 \mathrm{~cm}, \mathrm{Max}=15.9 \mathrm{~cm})$. Stolon diameter was larger at $5 \mathrm{~m}$ than $2 \mathrm{~m}$ depth $\left(\mathrm{F}_{2,1055}=\right.$ $9.5, \mathrm{P}<0.000$ ), while fronds were significantly longer at greater depths $\left(\mathrm{F}_{2,985}=116.8, \mathrm{P}<\right.$ 0.000) (Fig. 5). 

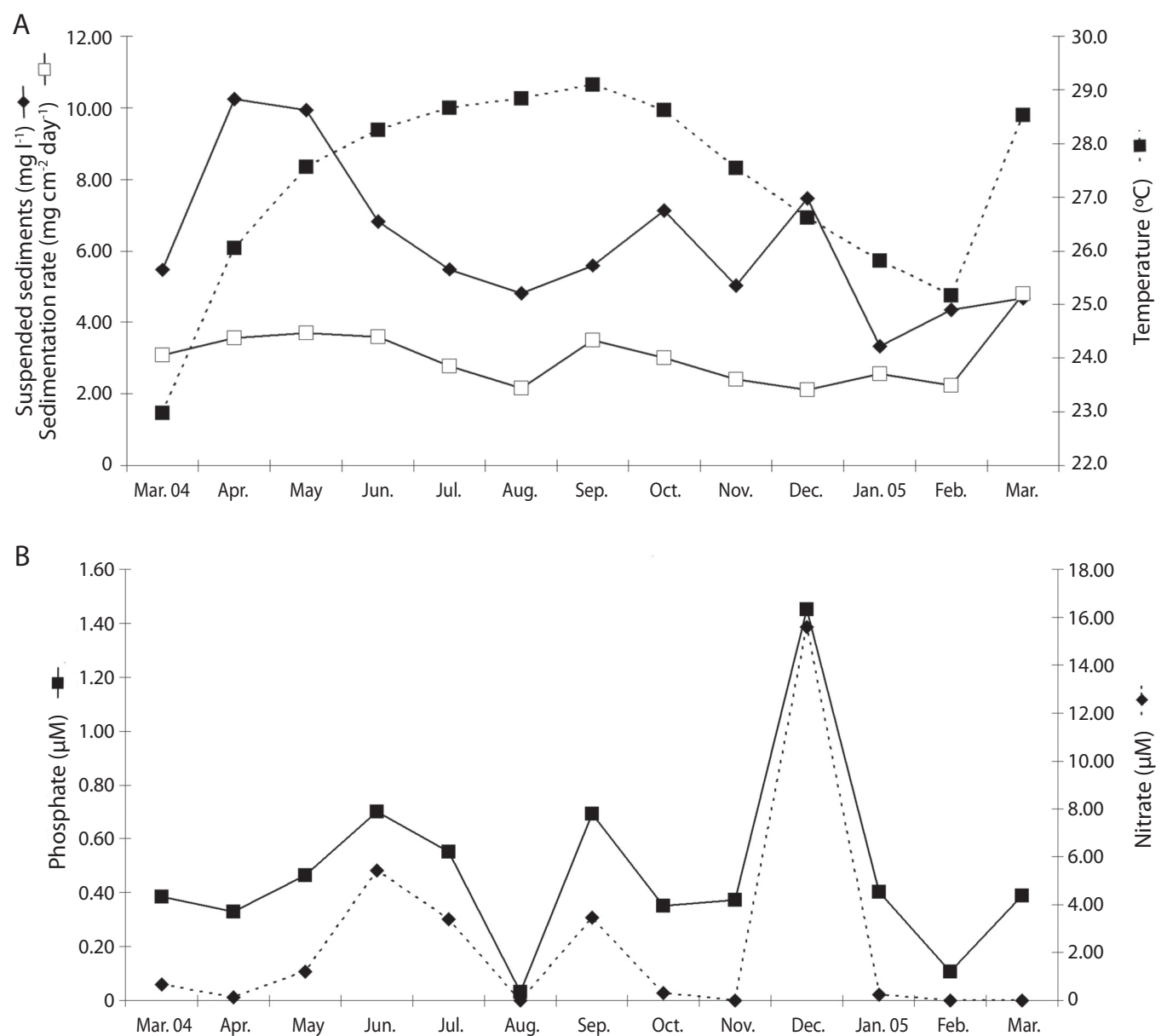

Fig. 3. Temporal dynamic of five principal physical-chemical factors, monitored from March 2004 to March 2005. (A) Suspended sediments $\left(\mathrm{mg} \mathrm{l}^{-1}\right)$, Sedimentation rate $\left(\mathrm{mg} \mathrm{cm}^{-2}\right.$ day $\left.^{-1}\right)$ and Temperature $\left({ }^{\circ} \mathrm{C}\right)$; $(\mathrm{B})$ Phosphate $(\mu \mathrm{M})$ and Nitrate $(\mu \mathrm{M})$.

Fig. 3. Dinámica temporal de cinco factores físico-químicos principales, monitoreados de Marzo 2004 a Marzo 2005. (A) Sedimentos en suspensión $\left(\mathrm{mg}^{-1}\right)$, Tasa de sedimentación $\left(\mathrm{mg} \mathrm{cm}^{-2} \mathrm{day}^{-1}\right)$ and Temperatura $\left({ }^{\circ} \mathrm{C}\right)$; $(\mathrm{B})$ Fosfato $(\mu \mathrm{M})$ and Nitrato $(\mu \mathrm{M})$.

Growth rate: Mean stolon growth rate was $11.7 \pm 6.2 \mathrm{~cm} \mathrm{month}^{-1}$, minimum in December $2004\left(1.4 \mathrm{~cm} \mathrm{month}^{-1}\right)$ and maximum in September $2004\left(33.2 \mathrm{~cm} \mathrm{month}^{-1}\right.$, Fig. 5). Significant differences were found between the stolon growth rates during the three sampling months $\left(\mathrm{F}_{2,144}=5.797\right.$ $\mathrm{p}<0.004$ ), mainly between March and September 2004 (Fig. 6).
Temporal algal percent coverage and frond density: Average percent coverage and frond density had similar dynamic patterns throughout the sampling time (Fig. 7). During the wet season the values of cover percentage tended to be $<40 \%$, however in September 2004 we documented a peak of $46.3 \%$, while the frond density during those months was $<29.5$ fronds $10 \mathrm{~cm}^{-2}$. After November both 

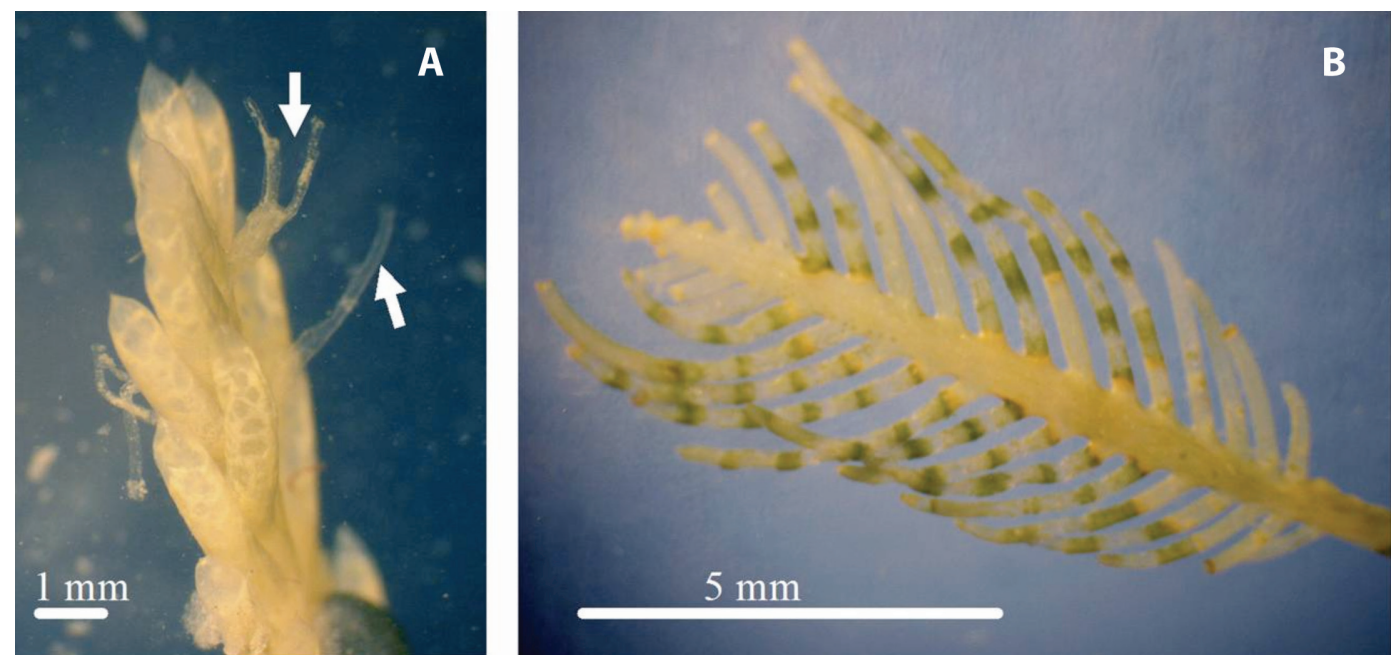

Fig. 4. Fronds after gamete release. (A) Detail of papillae that release gametes; (B) Detail of a frond tip after gametes were released.

Fig. 4. Frondas después de la liberación de gametos. (A) Detalle de las papilas por donde se liberan los gametos; (B) Detalle de la punta de la fronda luego de la liberación de gametos.
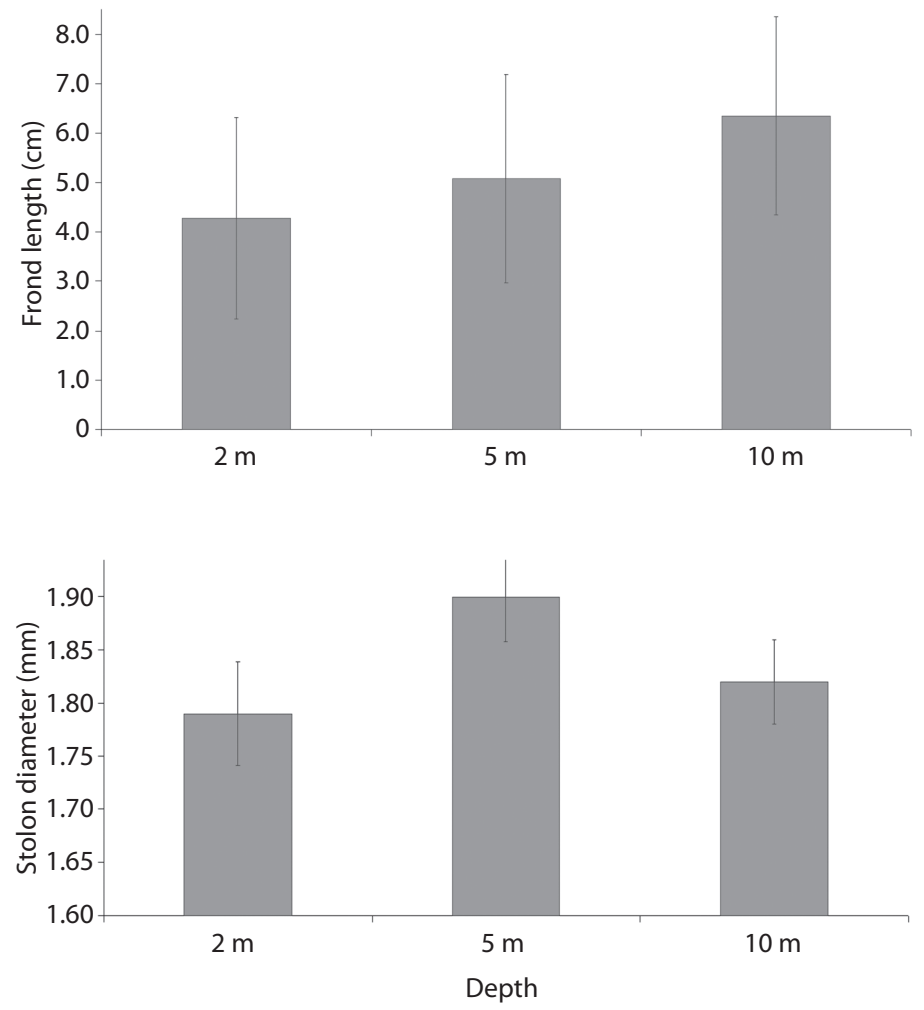

Fig. 5. Mean and standard deviation of stolon diameter $(\mathrm{mm})$ and frond length $(\mathrm{cm})$ at different depths.

Fig. 5. Promedio y desviación estándar del diámetro de estolón $(\mathrm{mm})$ y longitud de la fronda $(\mathrm{cm})$ a diferentes profundidades. 


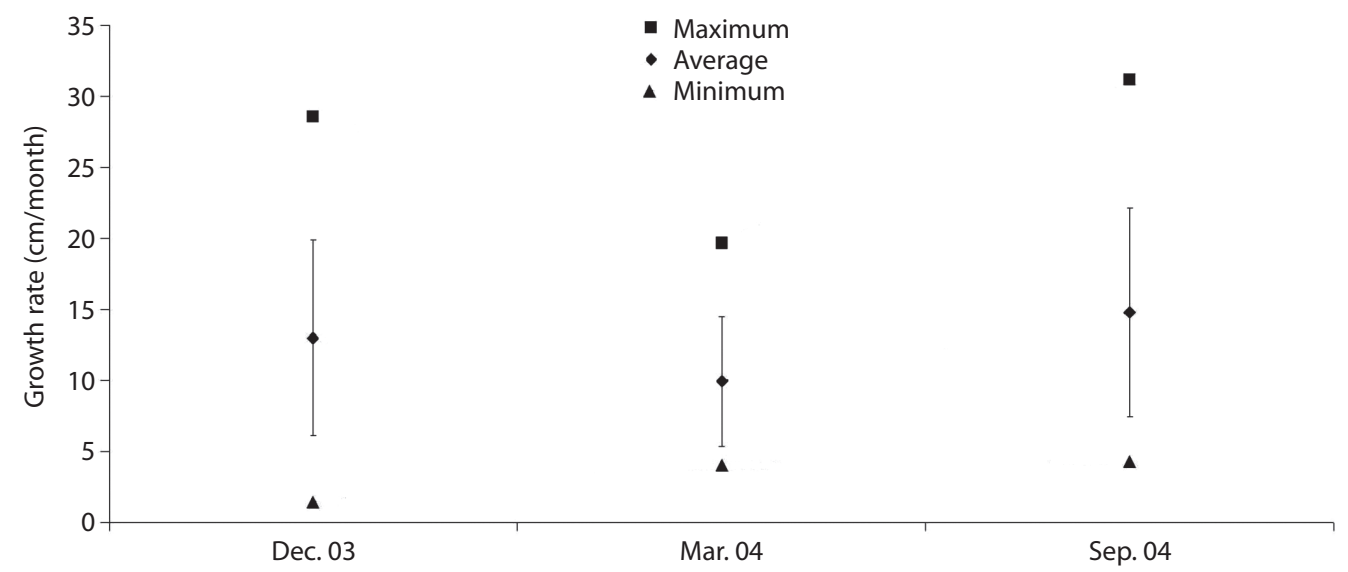

Fig. 6. In situ mean, maximum and minimum stolon growth of $C$. sertularioides after one month measured in December 2003, March 2004 and September 2004.

Fig. 6. Crecimiento promedio, máximo y mínimo in situ del estolón después de un mes medido en Diciembre 2003, Marzo 2004 y Setiembre 2004.

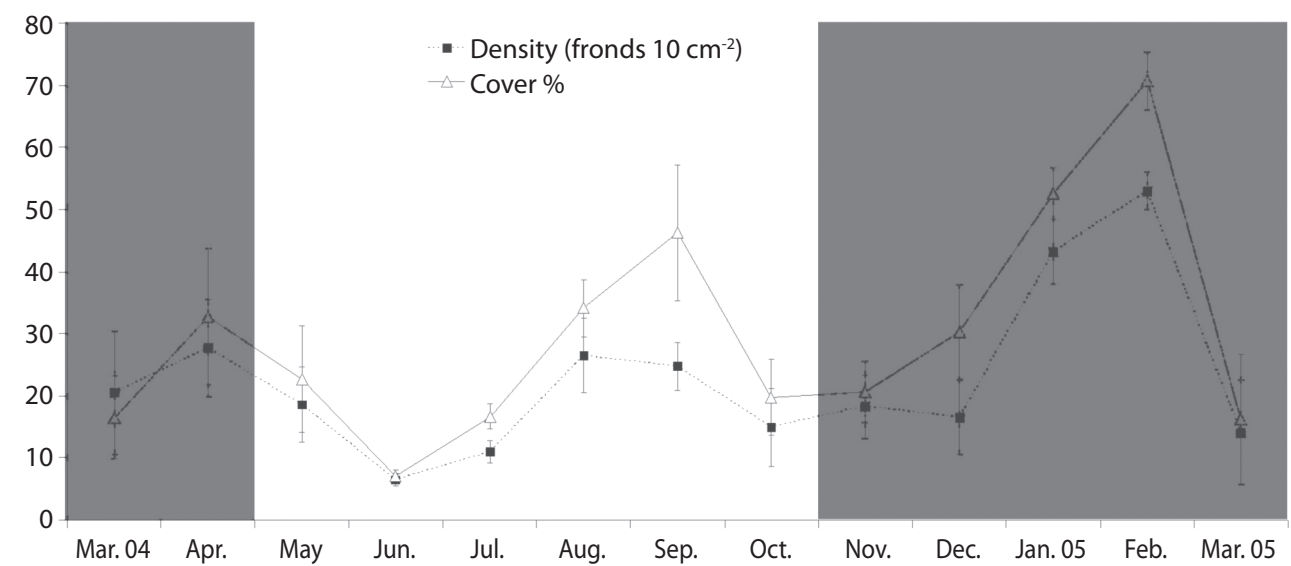

Fig. 7. Temporal dynamic of three sites average (La Penca, Playa Blanca, Isla Huevos) of frond density (\# of fronds $10 \mathrm{~cm}^{-2}$ ) and coverage (\%) of C. sertularioides, monitored from March 2004 to March 2005. Shaded area represents the dry upwelling season.

Fig. 7. Dinámica temporal del promedio de tres sitios (La Penca, Playa Blanca, Isla Huevos) de la densidad de frondas (\# de frondas $10 \mathrm{~cm}^{-2}$ ) y de la cobertura (\%) de C. sertularioides, monitoreada desde Marzo 2004 a Marzo 2005. El área sombreada representa la época seca de afloramiento costero.

parameters increase continuously until they reach the maximum values at February 2005, $70.7 \%$ cover and 50 fronds $10 \mathrm{~cm}^{-2}$, dropping in March to less than 20\% of cover and 20 fronds $10 \mathrm{~cm}^{-2}$ (Fig. 7).

The average percent cover $\left(\mathrm{F}_{5,183}=7.9\right.$, $\mathrm{p}<0.0001)$ and frond densities $\left(\mathrm{F}_{5,183}=13.5\right.$, $\mathrm{p}<0.0001)$ were statistically different between seasons (Fig. 8), being higher during the dry season (Fig. 8A and 8B). Also we found differences in coverage $\left(\mathrm{F}_{5,183}=12.1, \mathrm{p}=0.02\right)$ and frond density $\left(\mathrm{F}_{5,183}=20.5, \mathrm{p}<0.03\right)$ values, between sites. Playa Blanca exhibited the highest percent coverage and frond density values, 

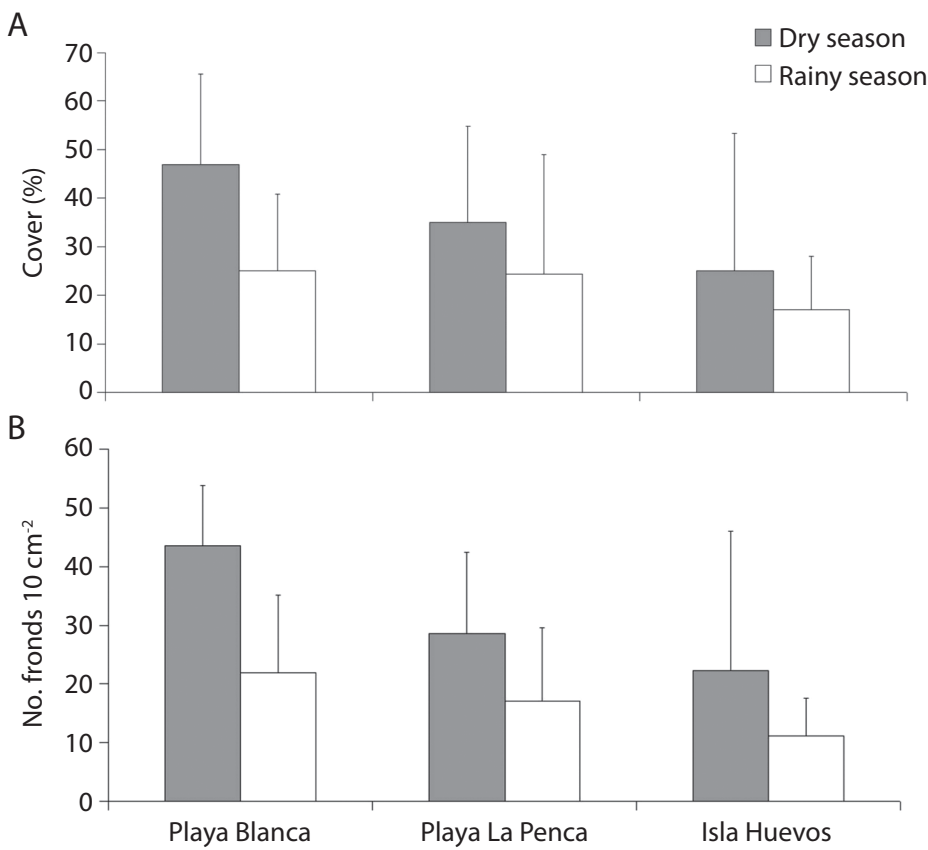

Fig. 8. Means and standard deviations of coverage percent (A) and frond density (B) at three sites during the dry and wet season, monitored from March 2004 to March 2005.

Fig. 8. Promedios y desviaciones estándar del porcentaje de cobertura (A) y densidad de frondas (B) en tres sitio durante las estaciones seca y lluviosa, monitoreadas desde Marzo 2004 a Marzo 2005.

while Isla Huevos showed the lowest values (Fig. 8A). When comparing seasons, we found higher during the dry season (Fig. 8B).

\section{DISCUSSION}

Caulerpa sertularioides is a native alga from the Pacific coast of Costa Rica, but since 2001 its abundance and growth rate have increased, colonizing a wide range of substrates and depths at Bahía Culebra (Fig. 9). In fact, we documented the greatest depth (23 m) reported for the species. In the Pacific coast of Panama, C. sertularioides grows from the intertidal zone to $16 \mathrm{~m}$ (Wysor 2004), while in Colombia, it grows to $1 \mathrm{~m}$ deep (Schnetter \& Bula-Meyer 1982). In the Caribbean and Central Pacific, $C$. sertularioides grows in reef habitats to a depth of $10 \mathrm{~m}$ (Littler \& Littler 2000, 2003). However, C. sertularioides has not been found as deep as other Caulerpa species, such as $C$. taxifolia in the Mediterranean that grows from 0-30 m deep, with highest densities between 5-15 m (Belsher \& Meinesz 1995). C. sertularioides at Bahía Culebra grew faster $\left(1.1 \mathrm{~cm} \mathrm{day}^{-1}\right)$ than some other Caulerpa species. For example, Williams et al. (1985) reported that $C$. mexicana grew $1.0 \mathrm{~cm} \mathrm{day}^{-1}$, while $C$. cupressoides $0.8 \mathrm{~cm} \mathrm{day}^{-1}$, and $C$. prolifera $0.4 \mathrm{~cm} \mathrm{day}^{-1}$. But slower than other Caulerpa species, such as $C$. taxifolia $(8 \mathrm{~cm}$ day $\left.^{-1}\right)$ and C. racemosa $\left(2 \mathrm{~cm}^{-1} \mathrm{day}^{-1}\right)$ (Dalton 2000), the first being one of the most invasive species of the genus.

We often observed floating $C$. sertularioides fronds and stolons during the study period, which suggest that local spreading is mainly driven by fragmentation of the thallus and dispersion around the bay by currents. As described by Benzie et al. (2000), C. sertularioides can has the capacity to resist high solar radiation allows its thalli to float for several 


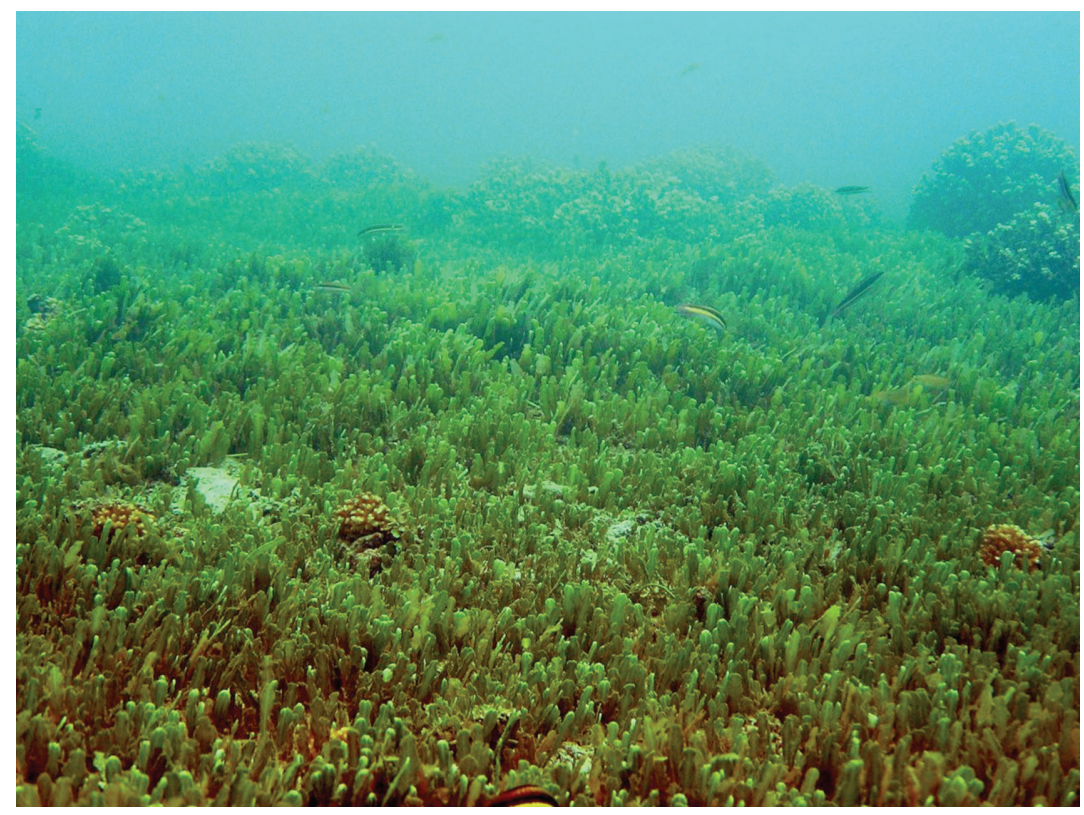

Fig. 9. Caulerpa sertularioides overgrowing corals, March 2004, Bahía Culebra.

Fig. 9. Parche de Caulerpa sertularioides, nótese como sobrecrecen el coral. Marzo 2004, Bahía Culebra.

days without desiccation until it reaches a substrate to grow. Once a thallus has colonized a substrate, it can easily spread, due to intrinsic characteristics of the species, such as rapid and efficient growth (Collado-Vides \& Robledo 1999). Thallus attachment is favored at sites with large coarse sediment. We found that coverage and density of the fronds was higher at sites with substrate composed mainly by Pocillopora spp. fragments (a common coral species at Playa La Penca, Ocotal and Playa Blanca). Most of these reefs develop over a structure of dead coral (Glynn et al. 1983, Cortés 1997, Jiménez 1998) which provide an appropriate surface that favors the attachment of the $C$. sertularioides stolons and rhizoids (Dumay et al. 2002). While substrates composed by fine sediments are less likely to be colonized by $C$. sertularioides. Sites with the highest coverage of $C$. sertularioides were located adjacent to coastal development, such as hotels, human communities, boat anchorage sites as well as complex coral reef structures. At sites, such as Playa Penca, Ocotal and Playa Blanca (Fig. 1 ), with coral reefs present, the bottom was composed of coarse sediments from fragments of dead coral (Pocillopora spp.), where the algae can attach easily.

In addition, frond and stolon morphology can adapt also to a combination of physical factors such as depth and substrate, as has been found for other Caulerpa species (Meinesz et al. 1995). When C. sertularioides grew on rocky substrates in shallow water the stolon was thicker, this adaptation allows the alga to hold to the substrate and resist the swell. Fronds in theses shallow depths (high solar radiation) tended to be smaller, and sometimes were not present. At greater depths and in finer sediments, stolons were thinner and more branched. This adaptation allows the alga to intercalate into fine sediments, and to easily obtain nutrients. This change in morphology with depth has been previously found to occur with Caulerpa cupressoides, where fronds size decreased as the swell influence increased (Collado-Vides \& Robledo 1999). This adaptation provides (i) resistance to strong hydrodynamic forces (Collado-Vides \& Robledo 1999) in high energy coastal zones, and (ii) efficiency of nutrient uptake. 
High genetic variability due to sexual reproduction of this opportunistic species at Bahía Culebra may promote adaptation to different environmental physical-chemical conditions (i.e depth, temperature, water motion, nutrients) (Allendorf \& Lundquist 2003). This is evident at the bay, where $C$. sertularioides showed morphological differences when growing on different substrates and depths, favoring local spreading of the green alga (ColladoVides \& Robledo 1999). As Clifton (1997) and Clifton and Clifton (1999) demonstrated for other species of Caulerpa, C. sertularioides in Bahía Culebra exhibit a synchronous release of sexual gametes and fertilization occurs in the water column. This green alga transforms all its vegetative inner content into gametes (holocarpic) that are released by papillae in the stolons and fronds (Dawes 1981, Bold \& Wynne 1985, Van den Hoek et al. 1998), leaving the cell walls empty, which make the thallus turn white (Van den Hoek et al. 1998).

Bahía Culebra, as in Gulf of California (Mexico), percent coverage and frond density of C. sertularioides seasonally fluctuated in relation to environmental factors (Scrosati 2001). During the dry season, when upwelling occurs, percent coverage and frond density increased. Such high algal biomass is typically caused by the presence of high nutrients concentrations (Bell 1992, Lapointe 1997, Szmant 2002) as during upwelling events. These nutrients are rapidly taken up from the environment, and are consumed in relatively short time periods (Rodríguez-Sénz 2005, J. Acuña-González pers. comm.).

Coverage and frond density decreased $40 \%$ in March $(2004,2005)$, one month after the upwelling peak (Fig. 7). This is consistent with Rodríguez-Sáenz (2005) who found that phytoplankton concentration and zooplankton density decreased after upwelling in Bahía Culebra as evident with other algal biomasses (e.g. Ulva spp. and Dictyota spp., pers. observ.) that clearly decreased.

Although coverage and density of $C$. sertularioides decreased during some months of the rainy months when nutrients decrease, it remained covering an average of $10 \%$ of the substrate (Fig. 7). In Uva Island, Panama, Smith et al. (2010) found that the maintenance of $C$. sertularioides patches, where there are no external nutrient inputs from the upwelling, is due to an association with epiphytic cyanobacteria, together with spatial refuges, suggesting mechanisms that maintain $C$. sertularioides near reef systems in the absence of high nutrients. Then from August to September the cover and frond density increased again when precipitation, organic material as well as phytoplankton biomass and zooplankton abundance increase in the bay (Rodríguez-Sáenz 2005).

Algal frond density and cover porcentage may be related to nutrient concentration in the environment, and our study suggests that a non-natural supply of nutrients during the wet season may trigger algae overgrowth, as has been reported in other areas (Lapointe 1997, Schaffelke \& Klumpp 1997, Little 2000). This is of concern because in Bahía Culebra there is no infrastructure to treat water derived from human activities, such as golf courts, hotels and agriculture. Phosphate and nitrate are the most important nutrients influencing algal growth at the bay, that can come from upwelling and anthropogenic sources, spreading at Bahía Culebra mainly by currents (Jiménez 1998). Water quality near coastal communities is currently a global problem (PNUMA 2007) and nutrient overloading in the ocean is one of the factors influencing coastal water quality and can have effects on different ecosystem dynamics, such as those in coral reefs (Fabricius 2005). Thus, nutrient supply in Bahía Culebra must be better understood to determine non-natural sources and to improve coastal management.

Although decreasing and increasing nutrient concentrations may have an important role in driving algal patterns, it can act in synergy with the temperature, which is another of the main abiotic factors influencing the dynamic in the bay (Fig. 3). Coverage and frond density of $C$. sertularioides can increase with nutrient uploads, however there is a peak in the values of those measurements in February with lower temperatures, during the upwelling, than in September, during the rainy season (Fig. 7). 
According to Terrados and Ros (1992) seasonal adaptations of macroalgae, are more common in temperate regions and in areas where upwelling occurs. These seasonal temperature variations can cause algal physiological adaptations in response to photosynthetic and growth requirements. At Bahía Culebra, we registered temperature differences of $10^{\circ} \mathrm{C}$ between seasons, which increase probabilities of a synergic action with high nutrient concentration on $C$. sertularioides abundance. Other Caulerpa species, such as $C$. taxifolia, have demonstrated the capacity to adapt to low temperatures (Jousson et al. 2000), providing the ability for growth at deeper depths and large temperature ranges (Belsher \& Meinesz 1995), thus increasing its invasive capacity (Allendorf $\&$ Lundquist 2003). Another important factor may be the attenuation of herbivory in upwelling environments, as suggested by Floeter $\mathrm{et}$ al. (2005) and Smith (2008), however this factor was not measured in our study.

\section{ACKNOWLEDGMENTS}

We are grateful to Davis Morera, Eva Salas, Bernadette Bezy, Eddy Gómez and Eleazar Ruiz for their collaboration in the field and in the laboratory. Specially thank to Bernadette Bezy for revising the English. We also want to thank the Costa Rican Institute of Tourism (ICT) by facilitating us the installations in Playa Panama and to the National Meteorological Institute of Costa Rica for providing meteorogical data. This manuscript was improved with the comments made by Ricardo Soto, Gerardo Ávalos and Javier Carrión. This work was supported through the Ecodesarrollo de Papagayo project and by project no. 80898-013, of the Vicerrectoría de Investigación, Universidad de Costa Rica.

\section{RESUMEN}

Desde el 2001 se ha observado una propagación del alga verde Caulerpa sertularioides en Bahía Culebra, zona de afloramiento costero, en el Pacífico norte de Costa Rica. El muestreo se llevó acabo entre Diciembre 2003 a marzo
2005, en varias localidades de Bahía Culebra. En este estudio se presentan los patrones de distribución, cobertura, tasa mensual de crecimiento, adaptaciones reproductivas y variaciones morfológicas del largo de la fronda y diámetro del estolón de Caulerpa sertularioides, a diferentes factores ambientales físico-químicos en Bahía Culebra. Esta alga se extiende hasta profundidades de $23 \mathrm{~m}$, en una gran variedad de sustratos. Los estolones se extienden rápidamente, con un crecimiento máximo de $31.2 \mathrm{~cm} \mathrm{mes}^{-1}$. Esta alga se propaga principalmente por la fragmentación de sus frondas y estolones, así mismo se reproduce sexualmente liberando gametos a la columna de agua. Estos modos de reproducción promueven la adaptación de esta especie oportunista, a los cambios ambientales, tanto químicos, como físicos, de la bahía. Al mismo tiempo esta alga presenta variaciones en el largo de sus frondas y el diámetro del rizoma, adaptándose a diferentes profundidades y condiciones de la época del año. El porcentaje de cobertura y densidad de frondas aumentan durante la época seca, cuando emergen aguas frías y nutrientes por el afloramiento costero. Por otro lado, en la época lluviosa estas medidas decrecen, sin embargo se presenta un pico en setiembre, cuando la precipitación aumenta y llega una carga extra de nutrientes a la bahía por escorrentía. La plasticidad morfológica y fisiológica de $C$. sertularioides, en sinergia con su propagación clonal, proveen a esta alga con una gran adaptabilidad a los cambios en temperatura y nutrientes de Bahía Culebra.

Palabras clave: Caulerpa sertularioides, afloramiento costero, América Central, Bryopsidales, nutrientes, tasa de crecimiento.

\section{REFERENCES}

Allendorf, F.W. \& L.L. Lundquist. 2003. Introduction: population biology, evolution, and control of invasive species. Conserv. Biol. 17: 24-30.

Bell, E.I. 1992. Eutrophication and coral reefs, some examples in the Great Barrier Reef lagoon. Wat. Res. 5: 553-568.

Belsher, T. \& A. Meinesz. 1995. Deep water dispersal of the tropical alga Caulerpa taxifolia introduced into the Mediterranean. Aquat. Bot. 51: 163-169.

Benzie, J.A.H., E. Ballment, J.R.M. Chisholm \& J.M. Jaubert. 2000. Genetic variation in the green alga Caulerpa taxifolia. Aquat.Bot. 66: 131-139

Bold, H.C. \& M.J. Wynne. 1985. Introduction to the Algae: Structure and Reproduction. Prentice-Hall, New Jersey. 720 p.

Brénes, C., B. Kwiecinski, L. D’Croz \& J. Cháves. 1995. Características oceanográficas de la plataforma Pacífica de América Central y aguas oceánicas adyacentes. PRADEPESCA, Panamá. 75 p. 
Cintrón, G., J.R. García \& F. Geraldes. 1994. Manual de métodos para la caracterización y monitoreo de arrecifes de coral. W.W.F., Washington D.C. 67 p.

Clarke, K.R. \& R.M. Warwick. 1994. Change in Marine Communities: An Approach to Statistical Analysis and Interpretation. Plymouth Marine Laboratory, United Kingdom. 144 p.

Clifton, K.E. 1997. Mass spawning by green algae on coral reefs. Science 275: 1116-1118.

Clifton, K.E. y L.M. Clifton.1999. The phenology of sexual reproduction by green algae (Briopsidales) on Caribbean coral reefs. J. Phycol. 35: 24-34.

Collado-Vides, L. \& D. Robledo. 1999. Morphology and photosynthesis of Caulerpa (Chlorophyta) in relation to growth form. J. Phycol. 35: 325-330.

Cortés, J. 1997. Biology and geology of coral reefs of the eastern Pacific. Coral Reefs 16 (Suppl.): S39-S46.

Dalton, R. 2000. Researchers criticize response to killer algae. Nature 406: 447.

Dawes, C.J. 1981. Marine Botany. John Wiley \& Sons, New York. 628 p.

Dawson, E.Y. 1944. The marine algae of the Gulf of California. Allan Hancock Pac. Exped. 3: 31-77.

Dawson, E.Y. 1962. Additions to the marine flora of Costa Rica and Nicaragua. Pac. Nat. 3: 375-395.

Dumay, O., G. Pergent, C. Pergent-Martini \& P. Amade. 2002. Variations in Caulerpenyne contents in $\mathrm{Cau}$ lerpa taxifolia and C. racemosa. J. Chem. Ecol. 28: 342-352.

Fabricius, K.E. 2005. Effects of terrestrial runoff on the ecology of corals and coral reefs: review and synthesis. Mar. Poll. Bull. 50: 125-146.

Fernández, C. \& J. Cortés. 2005. Caulerpa sertularioides, a green alga spreading aggressively over coral reef communities in Culebra Bay, North Pacific of Costa Rica. Coral Reefs, Reef Site 24:10.

Fernández-García, C., R. Riosmena-Rodríguez, B. Wysor, O.L. Tejada \& J. Cortés. 2011. Checklist of the Pacific marine macroalgae of Central America. Bot. Mar. 54: 53-73.

Floeter, S.R., M.D. Behrens, C.E.L. Ferreira, M.J. Paddack \& M.H. Horn. 2005. Geographical gradients of marine herbivorous fishes: patterns and processes. Mar. Biol. 147:1432-1793.

Gacia, E., M.M Littler \& D.S. Littler. 1996. The relationships between morphology and photosynthetic parameters within the polymorphic genes of Caulerpa. J. Exp. Mar. Biol. Ecol. 204: 209-224.

Glynn, P.W. \& J. Maté. 1997. Field guide to Pacific coral reefs of Panama. Proc $8^{\text {th }}$ Int.Coral Reef Symp. Panamá1: 145-166.

Glynn, P.W., E.M. Druffel \& R.B. Dunbar. 1983. A dead Central America coral reef tract: possible link with the Litle Ice Age. J. Mar. Res. 41:605-637.

Graham, L., J. Graham \& L.W. Wilcox. 2009. Algae. $2^{\text {nd }}$ Edit., Pearson Education Inc, San Francisco, California. $616 \mathrm{p}$

Howe, M.A. 1905. Phycological studies II. New Chlorophyceae, new Rhodophyceae and miscellaneous notes. Bull. Torrey Bot. Club 32: 563-586.

Jiménez, C.E. 1998. Arrecifes y comunidades coralinas de Bahía Culebra. Pacífico Norte de Costa Rica (Golfo de Papagayo). M.Sc. Thesis, Univ. Costa Rica. San José, Costa Rica. 218 p.

Jiménez, C.E. 2001. Arrecifes y ambientes coralinos de Bahía Culebra, Pacífico de Costa Rica: Aspectos biológicos, económicos-recreativos y de manejo. Rev. Biol. Trop. 49 (Supl. 2): 215-231.

Jiménez, C. E. \& J. Cortés. 2003. Growth of seven species of scleractinian corals in an upwelling environment of the Eastern Pacific, Golfo de Papagayo, Costa Rica. Bull. Mar. Sci. 72: 187-198.

Jousson, O., J. Pawlowski, L. Zaninetti, F.W Zechman, F. Dini, G. Di Giuseppe, R. Woodfield, A. Millar \& A. Meinesz. 2000. Invasive alga reaches California. Nature 408: 157-158.

Knowlton, N. 2000. Molecular genetic analysis of species boundaries in the sea. Hydrobiology420: 73-90.

Lapointe, B.E. 1997. Nutrient threshold for bottom-up control of macroalgal blooms on coral reefs in Jamaica and southeast Florida. Limnol. Oceanogr. 42: 1119-1131.

Lee, R.E. 2008. Phycology. 4th Edit. Cambridge University Press, Cambridge. 560 p.

Little, C. 2000. The Biology of Soft Shores and Estuaries. Oxford Unv. Press, New York. 252 p.

Littler, D.S. \& M.M. Littler. 2000. Carribbean Reef Plants. OffShore Graphics, Washington D.C. 541 p.

Littler, D.S. \& M.M. Littler. 2003. South Pacific Reef Plants. OffShore Graphics, Washington D.C. 331 p. 
Lorenzen, C. \& C. Jeffrey. 1978. Determination of chlorophyll in seawater. UNESCO Tech. Papers Mar. Sci. 35: 1-20.

Malta, E.J., D.G. Ferreira, J.J. Vergara, J.L. Perez-Llorens. 2005. Nitrogen load and irradiance affect morphology, photosynthesis and growth of Caulerpa prolifera (Bryopsidales: Chlorophyta). Mar. Ecol. Prog. Ser. 298: 101-114.

Meinesz, A., L. Benichou, J. Blachier, T. Komatsu, R. Lemée, H. Molenaar \& X. Mari. 1995. Variations in the structure, morphology and biomass of Caulerpa taxifolia in the Mediterranean Sea. Bot. Mar. 38: 499-508.

Ohba, H., Nashima, H. \& Enomoto, S. 1992. Culture studies on Caulerpa (Caulerpales, Chlorophyceae) III. Reproduction, development and morphological variation of laboratory-cultured C. racemosa var. peltata. Botanical Magazine, Tokyo 105: 589-600.

PNUMA (Programa de las Naciones Unidas para le Medio Ambiente). 2007. Perspectivas del medio ambiente mundial Geo4. Phoenix Desing AID, Dinamarca. 540 .

Raven, J.A. \& R.J. Geider. 1988. Temperature and algal growth. New Phytol. 110: 441-461.

Rodríguez-Sáenz, K. 2005. Distribución espacial y temporal de la biomasa, composición y abundancia del zooplancton, con énfasis en hidromedusas de Bahía Culebra durante La Niña 1999 y 2000. M.Sc. Thesis, Univ. Costa Rica, San José, Costa Rica. 156 p.

Rogers, C.S., G. Garrison, R. Grober, Z.M. Hillis \& M.A. Franke. 1994. Coral Reef Monitoring Manual for the Caribbean and Western Atlantic. U.S. National Park Service, TNC, WWF. 104 p.

Schaffelke, B. \& D.W. Klumpp. 1997. Growth of germlings of the macroalga Sargassum baccularia (Phaeophyta) is stimulated by enhanced nutrients. Proc. $8^{\text {th }}$ Int. Coral Reef Symp. Panamá 2: 1839-1842.

Schnetter, R. \& G. Bula-Meyer. 1982. Algas marinas del litoral Pacífico de Colombia. Edit. Gantner Verlag, Alemania. 287 p.

Scrosati, R. 2001. Population dynamics of Caulerpa sertularioides (Chlorophyta: Bryopsidales) from Baja California, Mexico, during El Niño and La Niña years. J. Mar. Biol. Assoc. U.K. 81: 721-726

De Senerpont Domis, L.N., P. Fama, A.J. Bartlett, W.F. Prud'homme van Reine, C. Espinosa \& G.C. Trono. 2003. Defining taxon boundaries in members of the morphologically and genetically plastic genus $\mathrm{Cau}$ lerpa (Chlorophyta). J. Phycol. 39: 1019-1037.
Smith, C.M. \& L.J. Walters. 1999. Fragmentation as a strategy for Caulerpa species: Fates of fragments and implications for management of an invasive weed. Mar. Ecol. 20: 307-319.

Smith, T. 2008. Temperature effects on herbivory for an Indo-Pacific parrotfish in Panamá: implications for coral-algal competition. Coral Reefs 27:397-405.

Smith, T.B., P. Fong, R. Kennison \& J. Smith. 2010. Spatial refuges and associational defenses promote harmful blooms of the alga Caulerpa sertularioides onto coral reefs. Oecologia 164: 1039-1048.

Strickland, J.D.H. \& T.R. Parsons. 1972. A Practical Handbook of Seawater Analysis. Fish. Res. Board Canada Bull. 310 p.

Szmant, A.M. 2002. Nutrient enrichment on coral reefs: is it a major cause of coral reef decline? Estuaries 25: 743-766.

Taylor, W.R. 1945. Pacific marine algae of the Allan Hancock Expeditions to the Galapagos Islands. Allan Hancock Pacific Expeditions, California. 528 p.

Terrados, J. \& J.D. Ros. 1992. The influence of temperature on seasonal variation of Caulerpa prolifera photosynthesis and respiration. J. Exp. Mar. Biol. Ecol. 162: 199-212.

Van den Hoek, C., D.G. Mann \& H.M. Jahns. 1998. Algae: An Introduction to Phycology. Cambridge Univ. Press, United Kingdom. 627 p.

West, E.L, A.R. Davis, P.B. Barnes \& J.T. Wright. 2009. The role of recreational activities in creating fragments of invasive Caulerpa taxifolia. J. Exp. Mar. Biol. Ecol. 376:17-25.

Williams, S.L, V.A. Breda, T.W. Anderson \& B.B. Nyden. 1985. Growth and sediment disturbances of Caulerpa spp. (Chlorophyta) in a submarine canyon. Mar. Ecol. Prog. Ser. 21:275-281.

Withgott, J. 2002. California tries to rub out the monster of the lagoon. Science 295: 2201-2202.

Wysor, B. 2004. An annotated list of marine Chlorophyta from Pacific coast of the Republic of Panama with a comparison to Caribbean Panama species. Nova Hedwigia 78: 209-241.

\section{Internet references}

Guiry, M.D. \& Guiry, G.M. 2011. AlgaeBase. World-wide electronic publication, National University of Ireland, Galway. http://www.algaebase.org; searched on 21 February 2011. 
